Pak. j. sci. ind. res. Ser. B: biol. sci. 2020 63B(3) 226-237

\title{
Effect of Mineral $N$ on $C$ and $N$ Dynamics of Rice and Wheat Residues under Different Moisture Levels
}

\author{
Ijaz Ali and Ghulam Nabi* \\ Land Resources Research Institute, National Agricultural Research Centre, Park Road, \\ Islamabad-45500, Pakistan
}

(received April 7, 2017; revised October 23, 2018; accepted October 24, 2018)

\begin{abstract}
Crop residue mineralization affects soil carbon $(\mathrm{C})$ and nitrogen $(\mathrm{N})$ dynamics during crop residue management in crop production. $\mathrm{C}$ and $\mathrm{N}$ mineralization dynamics of rice and wheat residues incorporated with and without mineral $\mathrm{N}$ under two moisture conditions were evaluated under laboratory conditions. Mineral N was applied @ $0.015 \mathrm{~g} / \mathrm{Kg}(\approx 30 \mathrm{Kg} / \mathrm{ha})$, whereas soil moisture was maintained at high $(\approx-15 \mathrm{KPa}$, near field capacity) and at low $(\approx-500 \mathrm{KPa})$ moisture levels during course of study. Periodic determinations on $\mathrm{CO}_{2}-\mathrm{C}$ and $\mathrm{N}$ mineralized were performed over a period of 120 days. The highest peaks for $\mathrm{CO}_{2}-\mathrm{C}$ occurred during first week of the study which then reduced gradually until it attained an equilibrium. High moisture level enhanced $\mathrm{CO}_{2}-\mathrm{C}$ flux by $14 \%$ than low moisture level. Combined application of crop residues and mineral $\mathrm{N}$ released $17 \%$ more $\mathrm{CO}_{2}-\mathrm{C}$ than crop residue treatments without mineral N.In residue applied treatments, immobilization was $40 \%$ higher at high moisture level than that at low moisture level. Application of rice and wheat residues in combination with mineral $\mathrm{N}$ caused both immobilizations followed by mineralization phases at both moisture levels. At high moisture level, maximum immobilization occurred during initial 15 days, while at low moisture level it continued till about 30 days. After day15, mineralization started which continued to increase during remaining period of study at high moisture and at low moisture mineralization initiated from day 60 onward. Mineralization in rice residue was faster than that in wheat residues. Immobilization of $\mathrm{N}$ continued progressively in residue alone treated soils at both moisture levels during study period. In residue treated soils, increase in soil moisture increased soil organic carbon (SOC) and soil water stable aggregates (WSA) significantly by $14 \%$ and $55 \%$ over control respectively.Combined application of crop residues and mineral $\mathrm{N}$ increased SOC by $43 \%$ and WSA by $59 \%$. This study indicated that incorporation of crop residues along with addition of mineral $\mathrm{N}$ in the presence of optimum moisture promoted its faster decomposition with a quicker mineral $\mathrm{N}$ release, more organic matter build up and soil structure improvement than crop residues incorporated without mineral $\mathrm{N}$.
\end{abstract}

Keywords: $\mathrm{C}$ and $\mathrm{N}$ mineralization, rice and wheat residues, soil moisture

\section{Introduction}

Soil organic carbon $(\mathrm{C})$ and nitrogen $(\mathrm{N})$ are the key indicators of soil quality and fertility in arable lands (Moreno-Cornejo, 2014). Crop residue management has a marked influence on carbon $(\mathrm{C})$ and nitrogen $(\mathrm{N})$ turn over in agro-ecosystems. Long term decline in soil fertility and quality is commonly associated with partial or complete removal or burning of above ground biomass (Kong et al., 2005; Lal, 2004). The crop residues incorporation is suggested as a potential means of sustaining soil fertility and productivity over the longterm (Singh and Rengel, 2007; Carter, 2002; Rasmussen and Parton, 1994) by improving physical and biological conditions of the soil (Ali and Nabi, 2016; Nyborg et al., 1995). Therefore, crop residues incorporation is

*Author for correspondence; E-mail: drgnabi@yahoo.co.uk encouraged inorder to recycle nutrients to soil and increase soil organic matter content (Ali and Nabi, 2016; Partey et al., 2014; Kone et al., 2010).

The rice-wheat cropping system in Pakistan is one of the major cropping systems practiced on an estimated area of $2.2 \mathrm{million} / \mathrm{ha}$ which produces (GOP, 2015). About 10-14 mg/ha crop residues are produced in Rice and wheat cropping system (Samra et al., 2003). In recent past whole crop biomass were removed from fileds during manual harvesting but recently with the advent of mechanized harvesting, only plant tops with grains are removed, while a major part of biomass is left in the fields as crop residues. Since left over residues interfere with tillage and seeding operations for the next crop, farmers often prefer to burn in situ, causing huge losses of soil organic matter (SOM) and nutrients, 
increasing $\mathrm{C}$ emissions, resulting in air pollution and reducing soil microbial activity (Kumar and Goh, 2000; Nguyen et al., 1994).

Decomposition of straw incorporated in soil is governed by many factors such as moisture, temperature and nutrient addition. Optimum soil moisture and mineral nitrogen input are the most important factors affecting straw decomposition. Soil moisture greatly enhance straw decomposition and $\mathrm{CO}_{2}$ flux (Tulina et al., 2009; Kruse et al., 2004; Lomander et al., 1998) or reduce it (Iqbal et al., 2009; Li et al., 2006). Nitrogen availability controls the kinetics of decomposition of crop residues, particularly those with high $\mathrm{C} / \mathrm{N}$ ratio such as cereals, when the $\mathrm{N}$ requirements of the soil decomposers are not fulfilled by the residue or soil $\mathrm{N}$ contents (Recous et al., 1995). Many researchers have reported that the addition of supplemental $\mathrm{N}$ has been successfully used to enhances decomposition of straw by lowering the $\mathrm{C}: \mathrm{N}$ ratios of soils in which straw has been incorporated (Abro et al., 2011; Chen et al. 2007; Potthoff et al., 2005).

Since residue decomposition rate determine the duration of net $\mathrm{N}$ immobilization and net $\mathrm{N}$ mineralization which consequently influence the net supply of $\mathrm{N}$ from residue to the ensuing crop and also on carbon storage in soil, whereas residue quality and environmental conditionsdictate decomposition rate. Therefore, the study of decomposition dynamics of crop residues and factors affecting, it has a key role in crop residue management in field.Consequently, a good knowledge of the $\mathrm{C}$ and $\mathrm{N}$ dynamics in soil and underlying causes is required to improve the synchronization of $\mathrm{N}$ supply with demand (Kumar and Goh, 2000).

Therefore, a study was conducted to evaluate $\mathrm{C}$ and $\mathrm{N}$ dynamics of rice and wheat residue with and without mineral nitrogen input under different moisture conditions at laboratory levels. This information will help in understanding residue management practices in long term field trials.

\section{Materials and Methods}

Soil characteristics and crop residues. The surface $(0$ $-15 \mathrm{~cm}$ ) soil was collected from the rice-wheat area of Sadhoke, $5 \mathrm{~km}$ south east of GT road, Kamonke, district Gujranwala, Punjab, Pakistan. The soil belonged to Gujranwala soil series (moderately well drained, noncalcareous, silty clay loam, hyperthermic Udic
Haplustalfs) based on Soil Survey Report, 1965. The collected soil was brought to LRRI, NARC. Soil was air dried,visible crop residue and pebbles were removed and sieved through a $2 \mathrm{~mm}$ sieve. The texture of soil was silty clay loam with $8.2 \mathrm{pH}, 0.15 \mathrm{dS} / \mathrm{m}$ EC, 20 $\mathrm{g} / \mathrm{Kg} \mathrm{CaCO}_{3}, 2.3 \mathrm{~g} / \mathrm{Kg}$ organic $\mathrm{C}, 8.2 \mathrm{mg} / \mathrm{Kg}$ mineral $\mathrm{N}, 2.8 \mathrm{mg} / \mathrm{Kg}$ ABDTPA extractable P and $125 \mathrm{mg} / \mathrm{Kg}$ of $\mathrm{K}$. The rice and wheat residues were collected from the farmer's field after the harvest of crops. The crop residues were oven dried at $70^{\circ} \mathrm{C}$ and chopped properly (0.5-1.0 cm pieces). Residues were analyzed for organic $\mathrm{C}$ by wet digestion (Nelson and Sommers, 1982) and total N (Jackson, 1982). Organic C in rice and wheat residues was 50.21 and $53.84 \%$ respectively, whereas total $\mathrm{N}$ was 0.73 and $0.46 \%$ respectively. The $\mathrm{C} / \mathrm{N}$ ratio of rice residue was 69, while that of wheat was 116 .

Experimental design and treatments. An incubation experiment was laid out in two factor factorial complete randomized design (CRD). Two moisture levels -15 $\mathrm{kP}_{\mathrm{a}}$ as High Moisture (HM) level and $-500 \mathrm{kP}_{\mathrm{a}}$ as Low Moisture (LM) level each maintained with 6 residue treatments: control (soil only, CS); soil + mineral N $(\mathrm{SMN})$; soil+wheat residue $(\mathrm{SWR})$; soil+ rice residue (SRR); soil + wheat residue + mineral $N(S W R+N)$ and soil + rice residue + mineral $\mathrm{N}(\mathrm{SRR}+\mathrm{N})$ each in four replications.

The prepared soil was split into two equal halves and placed on separate plastic sheet. One half was moistened to $\left(\approx-15 \mathrm{kP}_{\mathrm{a}}\right)$ and the other half moistened to $(\approx-500$ $\mathrm{kPa}$ )by sprinkling distilled water followed by gentle mixing. Soil water retention capacity at $\approx-15 \mathrm{kP}_{\mathrm{a}}$ and $-500 \mathrm{kP}_{\mathrm{a}}$ was determined by filter paper method (Deka et al., 1996). The moistened soil was sealed in plastic bags and allowed to cure for $72 \mathrm{~h}$ in a dark cold room to ensure uniform distribution of moisture throughout the soil and to attain moisture equilibrium. Both crop residues were applied @ $5.0 \mathrm{mg} / \mathrm{g}$ soil ( $9 \mathrm{mg} / \mathrm{ha})$ and mineral N@0.15 mg/g ( 30 Kg/ha). Urea fertilizer was used as mineral $\mathrm{N}$ source. Two separate sets, one for $\mathrm{CO}_{2}$ release and another for mineral nitrogen release were established. Both sets were incubated in a growth chamber maintained at $25^{\circ} \mathrm{C}$ temperature for 120 days.

Carbon mineralization. Moistened soil (200 g soil on dry weight basis) was taken in $1.0 \mathrm{~L}$ plastic jars. Rice and wheat residues and mineral $\mathrm{N}$ were poured into jar and thoroughly mixed with soil. A vial containing 10 $\mathrm{mL}$ of $1.0 \mathrm{M} \mathrm{NaOH}$ were placed in jars to trap the evolved $\mathrm{CO}_{2}$. Jars were covered with their lids and then 
lid and the jar interface was sealed with paper tape. An absolute control treatment (empty jar) was also maintained as blank. Alkali traps were removed at 1 , $3,5,10,15,20,30,45,60,75,90,105$ and $120 \mathrm{~d}$ (days) after incubation began and $\mathrm{CO}_{2}$ absorbed was analyzed by titration with $0.5 \mathrm{M} \mathrm{HCl}$ in the presence of $\mathrm{BaCl}_{2}$ (Anderson, 1982). During and after titration, jars were left open for $3 \mathrm{~h}$ to fully replenish with oxygen. The soil moisture content of the soil residue mixture was monitored throughout the study period by weighing and maintained by adding distilled water as needed periodically. At end of the experiment, soil in each jar was analyzed for soil organic carbon (Nelson and Sommers, 1982) and aggregate stability (Kemper and Rosenau, 1986). Soil stable aggregates (\%) $>250 \mu \mathrm{m}$ (macro-aggregates) were determined by using wet sieving apparatus of EijkelkampAgrisearch Equipment by the Netherland.

N mineralization. Moistened soil (500 g soil on dry weight basis) was taken in $0.5 \mathrm{~L}$ plastic jars. Rice and wheat residues and mineral $\mathrm{N}$ were thoroughly mixed as for the carbon mineralization study. Jars were covered with plastic sheets (with small vents for air exchange) to reduce evaporation from soil. The soil moisture content of the soil residue mixture was monitored throughout the study period by weighing and maintained by adding distilled water as needed periodically. On day $0,15,30,45,60,75,90,105$ and 120 after incubation, $20 \mathrm{~g}$ of soil from each jar was destructively sampled and analyzed for $\mathrm{N}$ mineralization. At each time samples so collected were air dried, sieved through $1 \mathrm{~mm}$ sieve and analyzed for mineral N (Keeney and Nelson, 1982).

\section{Calculation}

$\mathrm{CO}_{2}$ emission during the interval $\left(\mathrm{CO}_{2}-\mathrm{C}\right)$ was calculated as eq. 01 (Chen et al., 2009):

$\mathrm{CO}_{2}-\mathrm{C}(\mathrm{mg} / \mathrm{Kg}$ soil was added $)=\frac{\mathrm{N} \times 12 \times 1000}{\mathrm{Ws} \times 44}$..(eq.01)

where:

$\mathrm{V}_{\mathrm{b}}$ and $\mathrm{V}_{\mathrm{s}}=$ the volumes of $\mathrm{HCl}$ used in blank and sample respectively; $\mathrm{N}=$ the normality of $\mathrm{HCl} ; \mathrm{W}_{\mathrm{s}}=$ the weight of soil used per Jar.

Daily $\mathrm{CO}_{2}-\mathrm{C}$ flux was calculated as:
Daily $\mathrm{CO}_{2}-\mathrm{C}$ flux (mg/Kg soil/day) $=\frac{\underset{(\mathrm{mg} / \mathrm{Kg} \text { soil) }}{\mathrm{CO}_{2}-\mathrm{C}}}{\mathrm{t}_{\mathrm{i}}}$..(eq. 02) where:

$\mathrm{ti}=$ the time interval between each sampling day

Total $\mathrm{CO}_{2}-\mathrm{C}$ flux was calculated as:

Total $\mathrm{CO}_{2}-\mathrm{C}(\mathrm{mg} / \mathrm{Kg}$ soil $)=\sum_{120}^{1} \mathrm{CO}_{2}-\mathrm{C}(\mathrm{mg} / \mathrm{Kg}$ soil $) \ldots . .$. (eq.03)

Mineral $\mathrm{N}$ measured incontrolat each sampling day was subtracted from that of wheat residue (WR) and rice residue (RR), while mineral $\mathrm{N}$ measured in $\mathrm{N}$ applied treatment (SMN) was subtracted from that of $\mathrm{SWR}+\mathrm{SMN}$ and SRR+SMN to determine the net amount of mineralized $\mathrm{N}$ from or immobilized $\mathrm{N}$ by crop residues.

Statistical analysis.Collected data on total $\mathrm{CO}_{2}-\mathrm{C}, \mathrm{SOC}$ and soil stable aggregates were subjected to analysis of variance (ANOVA) under two factors factorial in Completely Randomized Design (CRD) (Gomez and Gomez, 1984). Least significant differences at $\mathrm{P} \leq 0.05$ was used to separate the means. At each sampling time means and standard errors were also computed for making comparisons. For statistical analysis, computer software "MSTAT-C" was used, while graphs were drawn in MS-Excel 2016.

\section{Results and Discussion}

Daily $\mathrm{CO}_{2}-\mathrm{C}$ flux. Effect of moisture levels and residue treatments on daily $\mathrm{CO}_{2}-\mathrm{C}$ flux are presented in Fig. 1.All treatments indicated a similar pattern of daily $\mathrm{CO}_{2}$ $-\mathrm{C}$ flux at both moisture levels. There was a very rapid $\mathrm{C}$ mineralization at the onset of the experiment during initial 6 days, which then levelled off gradually and ultimately became stable after day 30 . Beyond 30 days it continued to decrease but at much slower pace. Similar results have also been observed by Ali and Nabi (2016). The highest peaks for $\mathrm{CO}_{2}-\mathrm{C}$ in initial days of the incubation period was attributed to the microbial respiration and decomposition of easily decomposable organic compounds in crop residues during this time (Curtin et al., 1998; Krieft et al., 1987) which induced microbial growth initially and decreased afterwards due to the exhaustion of those substances (Kachroo et al., 2006; Khalil et al., 2005; Mishra et al., 2001). Trinsoutrot et al. (2000),Martens (2000) and Stevenson (1986) observed that easily decomposable compounds like carbohydrate and amino acid content contribute to the 
majority of $\mathrm{CO}_{2}$ efflux from soil rather than the soil phenolic acid content.

In the beginning of the experiment, there were large variationsin daily $\mathrm{CO}_{2}-\mathrm{C}$ flux among the treatments. However, these differences were narrowed down by the day 30 of the study. Overall $\mathrm{CO}_{2}-\mathrm{C}$ flux from crop residues with mineral $\mathrm{N}$ input were higher throughout the experimental period. Regardless of the residue type or moisture level, all treatments produced highest daily $\mathrm{CO}_{2}-\mathrm{C}$ flux at day 4 which then subsided sharply till day 10 and then further decreased gradually till day 30 . Maximum daily $\mathrm{CO}_{2}-\mathrm{C}$ flux observed from rice and wheat residues combined with mineral $\mathrm{N}$ input $(\mathrm{SRR}+\mathrm{N}$ and $\mathrm{SWR}+\mathrm{N}$ ) at day 4 was 20.30 and $19.52 \mathrm{mg} / \mathrm{Kg} / \mathrm{d}$ respectively, which was significantly higher than all other treatments at all incubation periods up to the day 28. Increase in the decomposition rate with increasing $\mathrm{N}$ availability may be attributed to increase in the population of more efficient decomposers in the microbial community having greater $\mathrm{N}$ requirements (Agren et al., 2001). These findings were consistent with Moran et al. (2005) and Lueken et al. (1962). Almost similar trend in maize straw with mineral $\mathrm{N}$

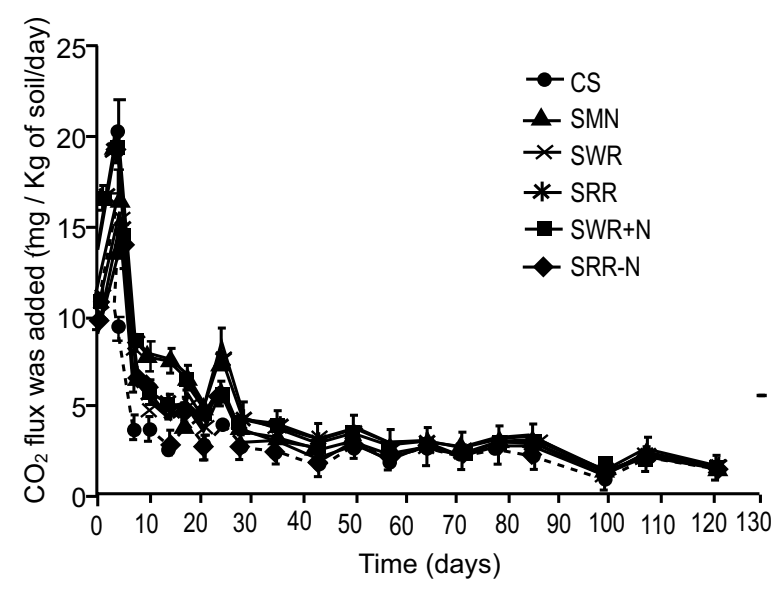

Fig. 1. Daily $\mathrm{CO}_{2}$ flux from rice and wheat residue with and without mineral $\mathrm{N}$.

where:

$\mathrm{CS}=$ control soil SMN $=$ soil + mineral nitrogen; $\mathrm{SWR}=$ soil + wheat residue; $\mathrm{SRR}=$ soil + rice residue; $\mathrm{SWR}+\mathrm{N}=$ soil + wheat residue with mineral nitrogen; $\mathrm{SRR}+\mathrm{N}=$ soil + rice residue with mineral nitrogen. Vertical bars represent standard error of means $(n=4)$

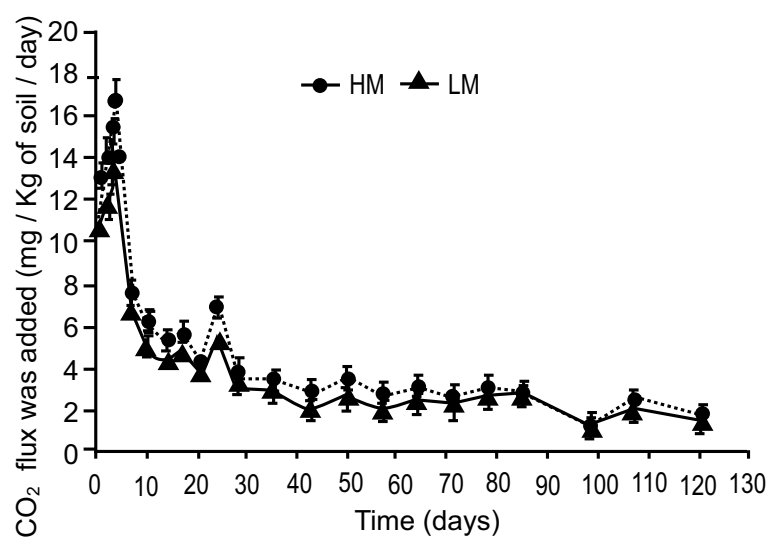

Fig. 2. Daily $\mathrm{CO}_{2}$ flux from rice and wheat residue at different soil moisture levels.

where:

$\mathrm{HM}=$ is the high moisture; $\mathrm{LM}=$ the low moisture. Vertical bars represent standard error of means $(n=4)$

was also observed by (Abro et al., 2011; Chen et al., 2007; Potthoff et al., 2005).

Moisture levels significantly affected daily $\mathrm{CO}_{2}-\mathrm{C}$ flux (Fig. 2). Increase in moisture hastened the evolution of daily $\mathrm{CO}_{2}-\mathrm{C}$ during decomposition of organic residues. Maximum daily $\mathrm{CO}_{2}-\mathrm{C}$ flux $(16.7 \mathrm{mg} / \mathrm{Kg} / \mathrm{d})$ was observed at day 4 for high moisture level which was significantly higher than low moisture level (14.2 $\mathrm{mg} / \mathrm{Kg} / \mathrm{d}$ ). During the rapid $\mathrm{C}$ mineralization phase (first week of incubation period), daily $\mathrm{CO}_{2}-\mathrm{C}$ flux was significantly higher for high moisture level as compared to low moisture at all duration of incubation period but was markedly higher with no significant differences afterwards. Increase in moisture enhanced the oxidation process of crop residues which consequently enhanced their decomposition process. Similar results were also reported by Tulina et al. (2009) and Hossain and Puteh (2013).

Total $\mathrm{CO}_{2}-\mathbf{C}$ flux. Total $\mathrm{CO}_{2}-\mathrm{C}$ emission for 120 days was significantly $(\mathrm{P}<0.0001)$ affected by soil moisture and treatments. But the interaction between moisture levels and crop residues treatments was nonsignificant. Higher moisture level significantly enhanced $\mathrm{CO}_{2}-\mathrm{C}$ flux by $14 \%$ (Fig. 3) than in low moisture level. This significant increase in $\mathrm{CO}_{2}-\mathrm{C}$ flux due to high moisture was in all treatments except control. Moisture enhances the oxidation process of crop residues which consequently enhances their decomposition 
process. Similarly, Zhang et al. (2008) and Chen et al. (2014) also reported increase in $\mathrm{CO}_{2}$ flux with increase in moisture content from the straw amended soil as compared to the non-amended soil.

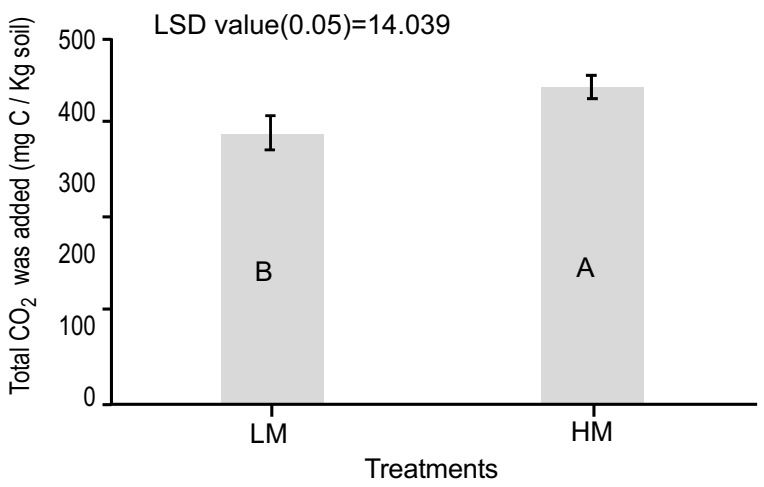

Fig. 3. Total $\mathrm{CO}_{2}$ flux from rice and wheat residues at different moisture levels.

where:

$\mathrm{HM}=$ high moisture; $\mathrm{LM}=$ low moisture. Vertical bars represent standard error of means $(n=4)$. Letters represent mean comparison.

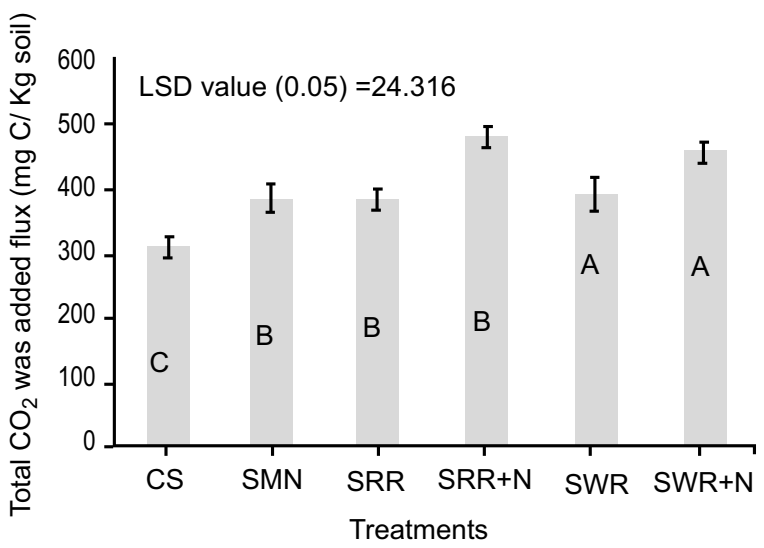

Fig. 4. Total $\mathrm{CO}_{2}$ flux from rice and wheat residues with and without mineral $\mathrm{N}$. where:

$\mathrm{CS}=$ control soil; $\mathrm{SMN}=$ soil + mineral nitrogen; $\mathrm{SWR}=$ soil + wheat residue; $\mathrm{SRR}=$ soil + rice residue; $\mathrm{SWR}+\mathrm{N}=$ soil + wheat residue with mineral nitrogen; $\mathrm{SRR}+\mathrm{N}=$ soil + rice residue with mineral nitrogen. Vertical bars represent standard error of means $(n=4)$. Letters represent mean comparison
Regardless of the moisture levels, treatments significantly differed in total $\mathrm{CO}_{2}-\mathrm{C}$ flux (Fig. 4). Mineral $\mathrm{N}$ and crop residue addition to soil significantly enhanced total $\mathrm{CO}_{2}-\mathrm{C}$ flux. Significantly highest $\mathrm{CO}_{2}-\mathrm{C}$ flux was recorded from crop residue with mineral $\mathrm{N}$ treatments $(\mathrm{SWR}+\mathrm{N}$ and $\mathrm{SRR}+\mathrm{N})$ compared to all other treatments followed by crop residue treatments without mineral $\mathrm{N}$ (SWR and SRR) which were significantly higher from control (CS), while at par with mineral $\mathrm{N}$ treatment (SMN). Addition of crop residue to soil acts as a substrate for soil microbes which results in increased microbial activities and consequently increased $\mathrm{CO}_{2}$ evolution. Mineral $\mathrm{N}$ input also significantly enhanced $\mathrm{CO}_{2}-\mathrm{C}$ flux in control, soil (CS) as well as in the crop residue amended soil. Addition of mineral $\mathrm{N}(\mathrm{SMN})$ released $19 \%$ higher $\mathrm{CO}_{2}-\mathrm{C}$ than control whereas mineral $\mathrm{N}$ input + crop residues $(\mathrm{SRR}+\mathrm{SMN}$ and $\mathrm{SWR}+\mathrm{SMN})$ enhanced $\mathrm{CO}_{2}-\mathrm{C}$ flux by $17 \%$ over crop residue treatments without mineral N (SRR and SWR). The enhancement of $\mathrm{CO}_{2}-\mathrm{C}$ release from control soil due to addition of mineral $\mathrm{N}$ showed accelerated soil organic matter decomposition. These findings are in agreement with (Muhammad et al., 2011: Moran et al., 2005) who reported a significant increase in $\mathrm{CO}_{2}$ emission with $\mathrm{N}$ fertilizer input to crop residue amended soil. Increase in the decomposition rate with increasing $\mathrm{N}$ availability may be attributed to increase in the population of more efficient decomposers in the microbial community having greater $\mathrm{N}$ requirements (Agren et al., 2001).

Nitrogen mineralization. Considerable differences in the pattern of $\mathrm{N}$ mineralization/immobilization in soil were observed when exposed to different moisture levels and rice and wheat residue application with and without mineral N (Fig. 5).

Incorporation of crop residue (wheat and rice)without mineral N (SRR and SWR)significantly reduced inorganic $\mathrm{N}$ content of soil (immobilized)at both moisture levels and this $\mathrm{N}$ immobilization persisted throughout the incubation period. This immobilization was faster during initial 15 days of incubation more and in high moisture than in low moisture level. At high moisture it attained a steady state after 15 days, while in low moisture immobilization further continued progressively during the study period. Also, there were no marked differences in $\mathrm{N}$ immobilization between rice and wheat residues applied without mineral N.Several researchers (Qian and Schoenau, 2002; Nicolardot et al., 2001; Van Kessel et al., 2000) found that residues with high $\mathrm{C} / \mathrm{N}$ ratio exhibit immobilization. Trinsoutrot et al. (2000) 


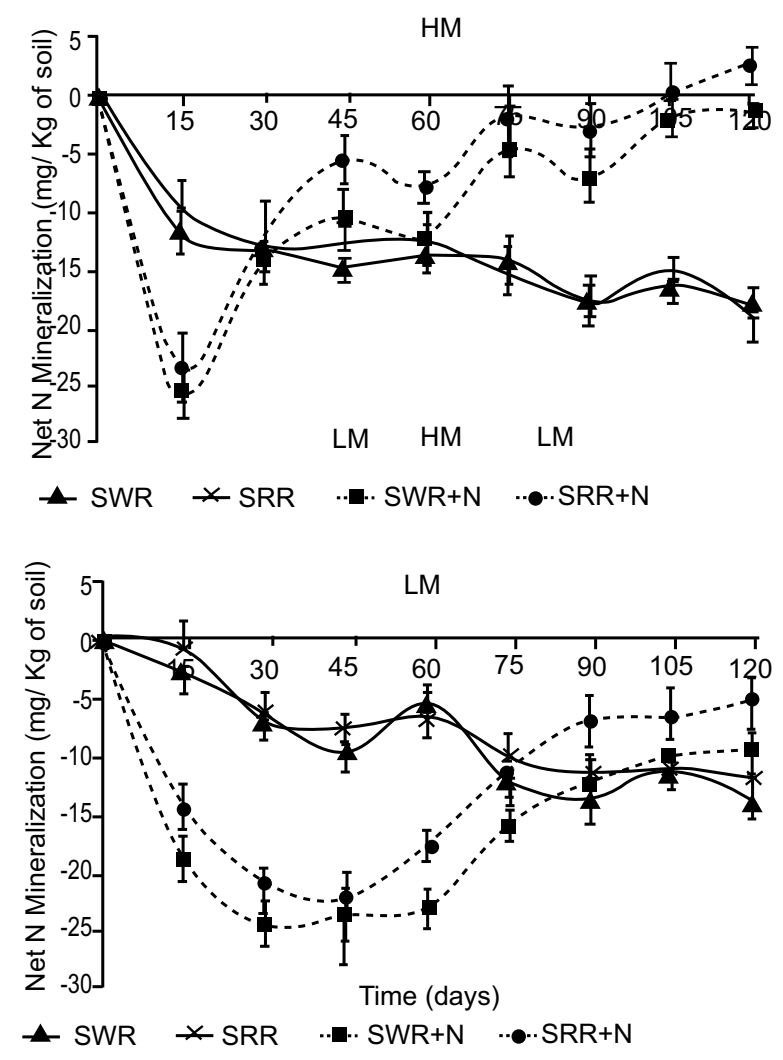

Fig. 5. $\mathrm{N}$ mineralization $\left(\mathrm{NO}_{3}-\mathrm{N}+\mathrm{NH}_{4}-\mathrm{N}\right)$ release from rice and wheat residues with and without mineral $\mathrm{N}$ at different moisture levels.

where:

$\mathrm{HM}=$ high moisture; $\mathrm{LM}=$ low moisture; $\mathrm{CS}=$ control soil; $\mathrm{SMN}=$ soil + mineral nitrogen; $\mathrm{SWR}=$ soil + wheat residue; $\mathrm{SRR}=$ soil + rice residue; $\mathrm{SWR}+\mathrm{N}=$ soil + wheat residue with mineral nitrogen; $\mathrm{SRR}+\mathrm{N}=$ soil + rice residue with mineral nitrogen. Vertical bars represent standard error of means $(n=4)$

related dynamics of soil mineral $\mathrm{N}$ mainly to the $\mathrm{C} / \mathrm{N}$ ratios of the crop residues applied to soil.Immobilization of mineral $\mathrm{N}$ by rice and wheat residues with high $\mathrm{C} / \mathrm{N}$ ratio could be due to the large demand for $\mathrm{N}$ by microorganisms proliferating rapidly in response to the availability of easily decomposable carbon compounds.

Incorporation of rice and wheat residues in combination with mineral $\mathrm{N}(\mathrm{SRR}+\mathrm{N}$ and $\mathrm{SWR}+\mathrm{N})$ gave rise to both immobilization and mineralization phases of soil mineral N. At both moisture levels, $\mathrm{SRR}+\mathrm{N}$ and $\mathrm{SWR}+\mathrm{N}$ immobilized a maximum amount of about 26 and 24 $\mathrm{mg} \mathrm{N} / \mathrm{Kg}$ soil respectively. But at high moisture level, maximum immobilization occurred during initial 15 days, while at low moisture level it continued 30 to 45 days, $\mathrm{SRR}+\mathrm{SMN}$ and $\mathrm{SWR}+\mathrm{SMN}$ resulted in 29 and $19 \%$ increase in immobilization at high moisture level and 26 and $17 \%$ increase in immobilization at low moisture level as compared to SRR and SWR respectively.Similar findings were also reported in white lupin residues (Doel et al., 1990) and carrot leaves (De Neve and Hofman, 2002). At high moisture, N mineralization started after 15 days, while at low moisture, $\mathrm{N}$ mineralization started after 45 days. The mineralization rate was faster at high moisture level than at low moisture level. In rice residue treatments, mineralization was higher than in wheat residue treatments. The presence of mineralization phase showed that urea hydrolyzed to mineral $\mathrm{N}$ and this increasing $\mathrm{N}$ availability increased the population of more efficient decomposers in the microbial community that have more $\mathrm{N}$ requirements (Agren et al., 2001) which enhanced the crop residue mineralization.

Soil moisture pronouncedly affected soil mineral N immobilization / mineralization pattern. Within 120 days of incubation period, SRR and SWR treatments immobilized $40 \%$ more $\mathrm{N}$ at high moisture level than that at low moisture level. Whereas, SRR+SMN and $\mathrm{SWR}+\mathrm{SMN}$ within 15 days immobilized about $25 \%$ and $38 \%$ more soil mineral $\mathrm{N}$ at high moisture level than at low moisture level, while in 120 days (at the termination of experiment), SRR+SMN and SWR + SMN re-mineralized about 105 and $89 \%$ of immobilized $\mathrm{N}$ at high moisture level and 64 and $49 \%$ at low moisture level respectively. These results showed that increasing moisture affected both $\mathrm{N}$ immobilization and mineralization processes in soil. This may be attributed to the more moisture availability for microbial activities at high moisture level. Optimum moisture availability is an essential requirement for higher microbial growth since low soil moisture can retard microbial activity by reducing intracellular water potential of microbes (Stark Firestone, 1995; Csonka, 1989) and diffusion of soluble substrates (Schjønning et al., 2003; Griffin, 1981).

Comparing rice and wheat residues, no prominent differences in $\mathrm{N}$ immobilization and mineralization were observed when applied without mineral $\mathrm{N}$ at both moisture levels but when applied in integration with 
mineral $\mathrm{N}$, wheat residue markedly immobilized higher amount of mineral $\mathrm{N}$ with lower remineralization ability than rice residues at both moisture levels.

In rice-wheat area of Pakistan, the time window between wheat harvesting and rice transplanting is about 60 days which provides enough time for residues to decompose and mineralize $\mathrm{N}$ if the crop residues are incorporated immediately after wheat harvesting. But the time window between rice harvesting and wheat sowing is short (20-25 days) thus incorporation must be done as early as possible after rice harvesting and additional dose of mineral $\mathrm{N}(\sim 25 \mathrm{~N} \mathrm{Kg} / \mathrm{ha})$ should also be applied to avoid $\mathrm{N}$ deficiency during germination and early growth. A light irrigation must also be applied just after residue incorporation to promote rapid mineralization of the residues. Crop residue incorporation will enhance soil organic matter and will improve soil structure.

Soil organic carbon (SOC). Soil organic carbon (SOC) contents were significantly affected by soil moisturelevels $(\mathrm{P}=0.0132)$ and treatments $(\mathrm{P}<0.0001)$. However, interaction between soil moisture and treatments was non-significant. Increase in soil moisture content increased SOC content significantly (Fig. 6). Increase in soil moisture content from low to high increased SOC by $14 \%$. Since soil moisture enhance soil microbial activities and crop residue decomposition

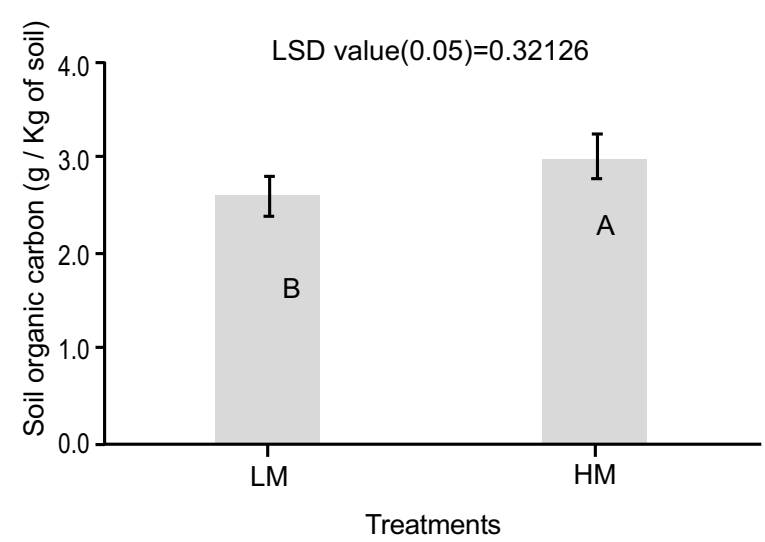

Fig. 6. Soil organic carbon under rice and wheat residues at different moisture levels. where:

$\mathrm{HM}=$ high moisture; $\mathrm{LM}=$ low moisture. Vertical bars represent standard error of means $(n=4)$. Treatments followed by different letters are significantly different at $\mathrm{P}<0.05$.Letters represent mean comparison. which releases organic compounds in soil which are retained by soil matrix resulting an increase in SOC content.

Regardless of the moisture levels, only the integrated application of rice and wheat residue with mineral $\mathrm{N}$ $(\mathrm{SRR}+\mathrm{N}$ and $\mathrm{SWR}+\mathrm{N})$ significantly increased SOC over control soil by $43 \%$. While no-significant differences in SOC was observed for alone application of crop residues (SRR, SWR) and mineral $\mathrm{N}$ over control (Fig. 7). Crop residues without mineral N (SRR and SWR) increased SOC over control soil by $8 \%$. Similar results were also reported by Poirier et al. (2013) and Esther et al. (2013) who observed increase in SOC with the incorporation of corn and wheat straw.SRR $+\mathrm{N}$ and SWR $+\mathrm{N}$ increased SOC content by $41 \%$ and $34 \%$ over SRR and SWR treatments. Our results showed that integrated use of mineral fertilizer with organic amendments are more effective in enhancing SOC content as compared to the sole application of organic residues. In a five-season experiment in a guar-wheat rotation in a sandy clay loam soil, Rezig et al. (2013) reported significantly higher SOC content from integrated application of crop residues than sole application of crop residues.

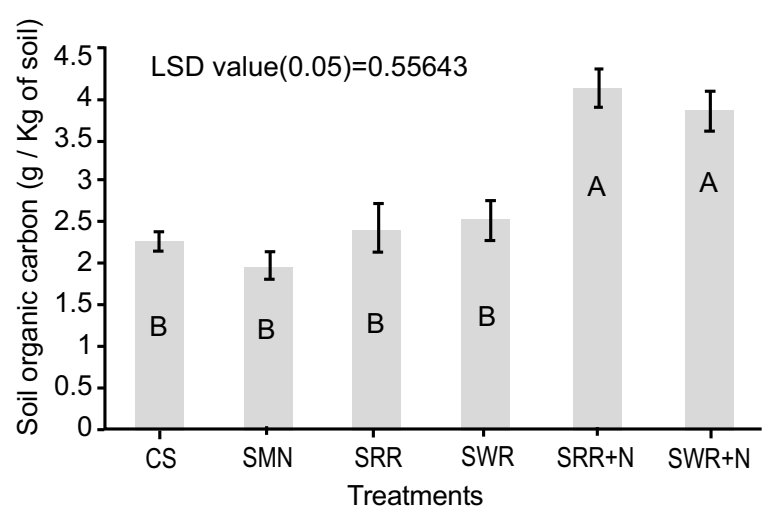

Fig. 7. Soil organic carbon under rice and wheat residues with and without mineral $\mathrm{N}$. where:

$\mathrm{CS}=$ control soil; $\mathrm{SMN}=$ soil + mineral nitrogen; $\mathrm{SWR}=$ soil + wheat residue; $\mathrm{SRR}=$ soil + rice residue; $\mathrm{SWR}+\mathrm{N}=$ soil + wheat residue with mineral nitrogen; $\mathrm{SRR}+\mathrm{N}$, soil + rice residue with mineral nitrogen. Vertical bars represent standard error of means $(n=4)$. Treatments followed by different letters are significantly different at $\mathrm{P}<0.05$. 


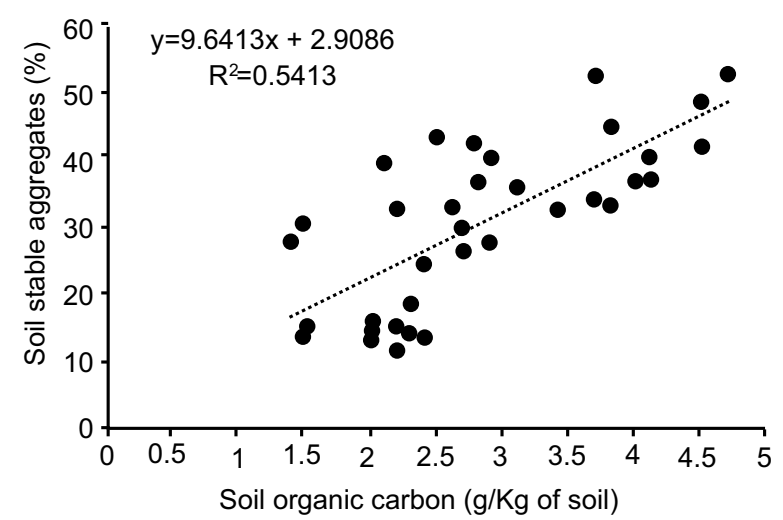

Fig. 8. Relation between soil organic carbon and soil water stable aggregates

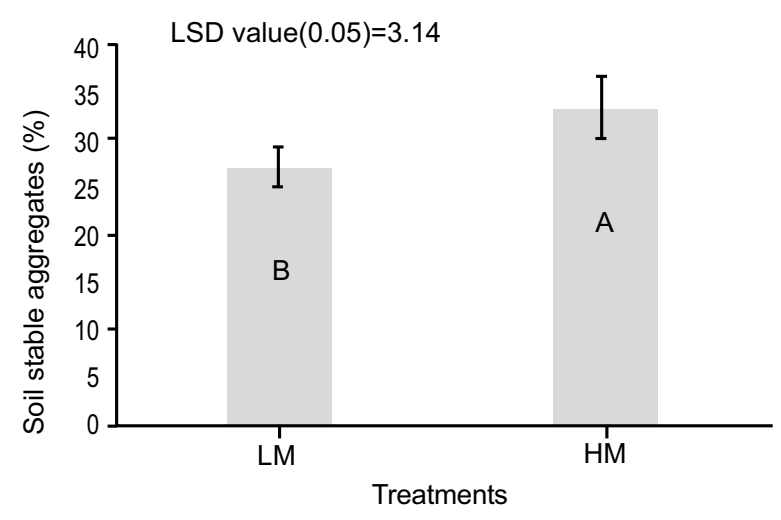

Fig. 9. Soil water stable aggregatesunder rice and wheat residues at bars represent standard error of means $(n=4)$. Treatments different moisture levels.

where:

$\mathrm{HM}=$ high moisture; $\mathrm{LM}=$ low moisture. Vertical followed by different letters are significantly different at $\mathrm{P}<0.05$.

Soil water stable aggregates (WSA). Similar trend for soil water stable aggregates (WSA) under different soil moisture levels and treatments was observed as that for SOC content. Because asignificantly good correlation $(\mathrm{r}=0.837 ; \mathrm{P}=0.000)$ of WSA with SOC was observed. This significant correlation may be attributed to the physical protection of SOC inside the soil aggregates (Tisdall and Oades, 1982). Regression analysis (Fig. 8) also showed that the increase in WSA due to soil organic carbon was $54 \%\left(\mathrm{R}^{2}=0.54\right)$ which was statistically significant $(\mathrm{P}<0.001)$. Similarly Stengel et al. (1984)

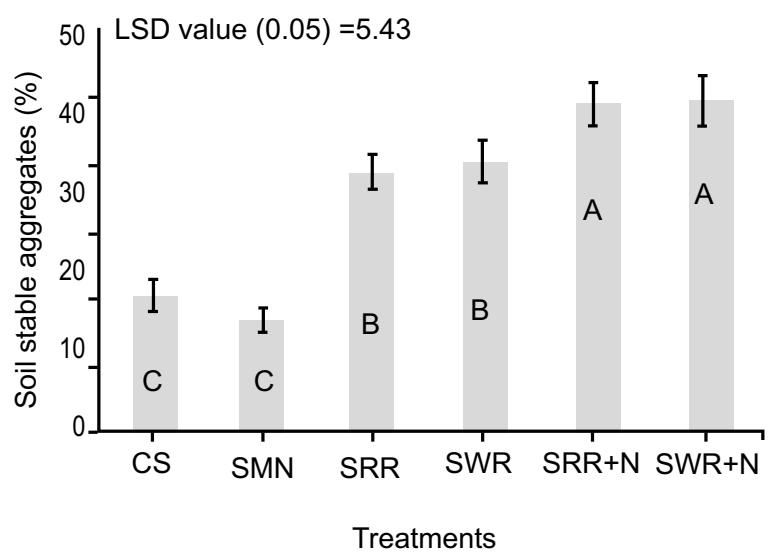

Fig. 10. Soil water stable aggregatesunder rice and wheat residues with and without mineral $\mathrm{N}$.

where:

CS, control soil; SMN, soil + mineral nitrogen; SWR, soil + wheat residue; SRR, soil + rice residue; $\mathrm{SWR}+\mathrm{N}$, soil + wheat residue with mineral nitrogen; $\mathrm{SRR}+\mathrm{N}$, soil + rice residue with mineral nitrogen. Vertical bars represent standard error of means $(n=4)$. Treatments followed by different letters are significantly different at $\mathrm{P}<0.05$.

observed a similar regression equation $(12.75+11.75$ $\left.\mathrm{SOC}(\%) ; \mathrm{R}^{2}=0.61, \mathrm{P}<0.001\right)$ for soil stable aggregates SOC.

Soil moisture levels $(\mathrm{P}=0.0003)$ and treatments $(\mathrm{P}<$ $0.0001)$ significantly affected WSA. Increase in soil moisture content significantly increased WSA (Fig. 9). Increase in WSA at high moisture content was $19 \%$ over low moisture content. High WSA due to high moisture content may be due to the high soil organic carbon content at high moisture level which act as a cementing agent for aggregate formation and stabilization (Chaney and Swift, 1984). Regardless of the soil moisture levels, rice and wheat residues both alone and together with mineral $\mathrm{N}$, increased soil aggregate stability significantly (Fig. 10). Rice and wheat residues with mineral $\mathrm{N}$ increased the amount of WSA by $59 \%$ and without mineral $\mathrm{N}$ by $48 \%$ over control soil, (Chivenge et al. 2011; Marten 2000, Aggarwal et al. 1995; Sarkar and Rathore, 1992) have also shown improved structure with organic residues applied to soil by increasing soil aggregate stability. Allison (1968) attributed the increase in soil aggregate 
stability to the release of cementing agents responsible for aggregation by soil micro-organisms upon organic residue decomposition.

\section{Conclusion}

Mechanized harvesting in rice wheat cropping system leaves behind about $4-5 \mathrm{mg} / \mathrm{ha}$ of crop residues which creates hindrance in seedbed preparation of succeeding crop. For a quick seedbed preparation, farmers burn these residues which creates soil health and environmental problems. Our observations showed that rice residue has faster $\mathrm{C}$ mineralization rates than wheat residues. Further, the mineralization rates were faster when residues were subjected to both mineral $\mathrm{N}$ and high moisture. Without mineral $\mathrm{N}$ addition, residues application caused immobilization of soil $\mathrm{N}$ up to the end of the experimental period (120 days), the application of mineral $\mathrm{N}$ and high moisture significantly enhanced its decomposition and initiated faster mineralization. Incorporated rice and wheat residues increased soil organic carbon by $18 \%$, while soil stable macroaggregates by $50 \%$ over un-amended soil.

\section{Acknowledgement}

Studies were conducted under Research for Agricultural Development Program (RADP) of Pakistan Agricultural Research Council, Islamabad, Financial support provided by RADP project is highly acknowledged.

Conflict of Interest. The authors declare no conflict of interest.

\section{References}

Abro, S.A., Tian, X., Wang, X., Wu, F., Kuyide, J.E. 2011. Decomposition characteristics of maize (Zea mays. L.) straw with different carbon to nitrogen $(\mathrm{C} / \mathrm{N})$ ratios under various moisture regimes. African Journal of Biotechnology, 10: 10149-10156.

Aggarwal, G.C., Sidhu, A.S., Sekhon, N.K., Sandhu,K.S., Sur, H.S. 1995. Puddling and N management effects on crop response in a rice-wheat cropping system, Soil Tillage Research, 36: 129-139.

Agren, G.I., Bosatta,E., Magill, A.H. 2001. Combining theory and experiment to understand effects of inorganic nitrogen on litter decomposition. Oecologia, 128: 94 ?98.

Ali, I., Nabi, G. 2016. Soil carbon and nitrogen mineralization dynamics following incorporation and surface application of rice and wheat residues. Soil \& Environment, 35: 207-215.

Allison, F.E. 1968. Soil aggregation - some facts and fallacies as seen by a microbiologist. Soil Science, 106: 1361743.

Anderson, J.P.E. 1982. Soil respiration. methods of \& soil analysis. Part 2. $2^{\text {nd }}$ ed, p. 831-871. In: Agron Monogr 9, ASA and SSSA, A. L. Page et al. (ed.) Madison, WI.

Carter, M.R. 2002. Soil quality for suitable land management: organic matter and aggregation interactions that maintain soil functions. Agronomy Journal, 94: 38-47.

Chaney, K., Swift, R.S. 1984. The influence of organic matter on aggregate stability in some British soils. Journal of Soil Science. 35: 223-230.

Chen, H., Norbert, B., Karl, S., Yakov, K. 2007. Effect of nitrogen and intensive mixing on decomposition of C labeled maize (Zea Mays L) residue in soils of different land use types. Soil and Tillage Research, 96: 114-123.

Chen, L., Zhang, J.B., Zhao, B.Z., Xin, X.L., Zhou, G.X., Tan, J.F., Zhao, J. H. 2014. Carbon mineralization andmicrobial attributes in strawamended soils as affected by moisture levels. Pedosphere, 24: 167-177.

Chen, X.L., Zhou, J.B., Liu, J.L., Gao, Z.X., Yang, X.Y. 2009. Effect of fertilization on carbon/nitrogen ratio of maize straw and its mineralization in soil. Chinese Journal of Applied Ecology, 20: 314-319.

Chivenge, P., Vanlauwe, B., Six, J. 2011. Does the combined application of organic and mineral nutrient sources influence maize productivity. A meta-analysis. Plant and Soil, 342: 1-30.

Csonka, L.N. 1989. Physiological and genetic responses of bacteria to osmotic stress. Microbiological Reviews, 52: 121-147.

Curtin, D., Selles, F., Wang, H., Campbell, C.A., Biederbeck, V.O. 1998. Carbon dioxide emissions and transformations of soil carbon and nitrogen during wheat straw decomposition. Soil Science Society of America Journal, 62: 1035-1041.

De Neve, S., Hofman, G. 2002. Quantifying soil water effects on nitrogen mineralization from soil organic matter and from fresh crop residues. Biological Fertilization Soils, 35: 379-386.

Deka, R.N., Wairiu, M., Mullins, C.E., Veenendaal, E.M., Townend, J. 1996. Use and accuracy of the filter paper technique for measurement of soil moisture stress. European Journal of Soil Sciences, 
46: $233-238$

Doel, D.S., Honeycutt, C.W., Halteman, W.A. 1990. Soil water effects on the use of heat units to predict crop residue carbon and nitrogen mineralization. Biology and Fertility of Soils, 10: 102-106.

Esther, O.J., Hong, T.X., Hui, G.C. 2013. Influence of straw degrading microbial compound on wheat straw decomposition and soil biological properties. African Journal of Microbiology Research, 7: 3597 3605.

GOP, Goverment of Pakistan 2015. Agricultural Statistics of Pakistan. Ministry of National Food Security and Research, Government of Pakistan, Islamabad, Pakistan.

Gomez, K.A., Gomez, A.A. 1984. Statistical Procedures for Agricultural Research, $2^{\text {nd }}$ eds. ISRRI John Wiley \& Sons Publication, New York, USA.

Griffin, D.M. 1981. Water potential as a selective factor in the microbial ecology of soils. In: Water Potential Relations in Soil Microbiology. J. F. Parr, W. R. Gardner, L. F. Elliott (eds.), pp. 141-151, SSSA Spec. Publ. 9. SSSA, Madison, WI.

Hossain, M.B., Puteh, A.B. 2013. Emission of carbon dioxide influenced by different water levels from soil incubated organic residues. Hindawi Publishing Corporation. The Scientific World Journal, 1-8.

Iqbal, J., Hu, R., Lin, S., Bocar, A., Feng, M. 2009. Carbon dioxide emissions from Ultisol under different land uses in mid-subtropical China. Geoderma, 152: 63-73.

Jackson, M.L. 1982. Soil Chemical Analysis. Varlag: Prentice-Hall Inc, England, New Jerssy, USA.

Kachroo, D., Dixit, A.K., Bhat, A.K. 2006. Decomposition of various residues and their nutrient release pattern under Alfisols of Jammu Region. Journal of Indian Society of Soil Science, 54: 342-344.

Keeney, D. R., Nelson, D.W. 1982. Nitrogen-inorganic forms. In: Methods of Soil Analysis Part 2. Chemical and Microbiological Properties, A. L. Page, R. H. Miller and D. R. Keeney (eds.), pp. 595-624. American Society of Agronomy and Soil Science Society of America, Madison, USA.

Kemper, W.D., Rosenau, R.C. 1986. Aggregate stability and size distribution. In: Methods of Soil Analysis, Part 1. A. Klute ( $2^{\text {nd }}$ eds.), pp. 425-442, Agron. Monogr. 9. ASA, Madison, WI.

Khalil, M.I., Hossain, M.B.,Schmidhalter, U. 2005. Carbon and nitrogen mineralization in different upland soils of the subtropics treated with organic materials.Soil Biology and Biochemistry. 37:
1507-1518.

Kone, F.J., Kouadio, Y., Yapo,E.S., Visser, M. 2010. Effects of spontaneous plant residues and rice straw incorporated in soil on growth and yield parameters of a lowland rice cultivar (Oryza sativa L.) in sub humid Tropical area, Côte D'ivoire. Journal of Applied Sciences Research, 6: 1581-1588.

Kong, A.Y.Y., Six, J., Bryant, D.C., Denison,R.F., van Kessel, C. 2005. The relationship between carbon input, aggregation, and soil organic carbon stabilization in sustainable cropping systems. Soil Science Society of America Journal, 69: 1078-1085.

Krieft, T.L., Soroker, E.,Firestone, M.K. 1987. Microbial biomass response to a rapid increase in water potential when dry soils is wetted. Soil Biology and Biochemistry, 19: 119-126.

Kruse, J.S., David, E., Kissel, M., Cabrera, L.2004. Effects of drying and rewetting on carbon and nitrogen mineralization in soils and incorporated residues. Nutrient Cycling in Agroecosystems, 69: 247-256.

Kumar, K.,Goh, K.M. 2000. Crop residues and management practices: effects on soil quality, soil nitrogen dynamics, crop yield and nitrogen recovery. Advances in Agronomy, 68: 197-319.

Lal, R. 2004. Soil carbon sequestration impacts on global climate change and food security. Science, 304: 1623-1627.

Li, X., Li, G., Qi,M., Bhupinderpal, S., Cui,Z.J., Rengel, Z. 2006. Decomposition of maize straw in saline soils. Biology and Fertility of Soils, 42: 366-370.

Lomander, A.,Kätterer, T., Andrén, O. 1998. Modelling the effects of temperature and moisture on $\mathrm{CO}_{2}$ evolution from top and subsoil using a multicompartment approach. Soil Biology and Biochemistry, 30: 2023-2030.

Lueken, H., Hutcheon,W.L., Paul, E.A. 1962. The influence of nitrogen on the decomposition of crop residues in the soil. Canadian Journalof Soil Science, 42: 277-288.

Martens, D.A. 2000. Plant residue biochemistry regulates soil carbon cycling and carbon sequestration. Soil Biology and Biochemistry, 32: 361-369.

Mishra, B., Sharma, P.K., Bronson, K.F. 2001. Decomposition of rice residue and mineralization of carbon, nitrogen, phosphorous and potassium in wheat field soil in Western Uttar Pradesh. Journal of Indian Society of Soil Science, 49: 419-424.

Moran, K.K., Six, J., Horwath, W.R.,van Kessel, C. 2005. Role of mineral-nitrogen in residue decom- 
position and stable soil organic matter formation. Soil Science Society of America Journal, 69: 17301736.

Moreno-Cornejo, J., Zornoza, R., Faz, A. 2014. Carbon and nitrogen mineralization during decomposition of crop residues in a calcareous soil. Geoderma, 230-231: 58-63.

Muhammad, W., Vaug, S.M., Dalal, R.C.,Menzies, N.W. 2011. Crop residues and fertilizer nitrogen influence residue decomposition and nitrous oxide emission from a Vertisol. Biology and Fertility of Soils, 47: 15-23.

Nelson, D.W., Sommers, L.E. 1982. Total Carbon, Organic Carbon and Organic Matter. pp. 539-577. In: Methods of Soil Analysis. Part 2. A. L. Page, R. H., Miller and D. R. Keeney (eds.), American Society of Agronomy, Madison, Wisconsin, USA.

Nguyen, B.C., Putaud, J.P., Mihalopoulos, N., Bonsang, B. 1994. $\mathrm{CH}_{4}$ and $\mathrm{CO}$ emissions from rice straw burning in south east Asia. Environmental Monitoring and Assessment, 31: 131-137.

Nicolardot, B., Recous, S., Mary, B. 2001. Simulation of $\mathrm{C}$ and $\mathrm{N}$ mineralisation during crop residue decomposition: A simple dynamic model based on the C:N ratio of the residues. Plant and Soil, 228: 83-103.

Nyborg, M., Solberg, E.D., Malhi, S.S.,Izau, S.R., Ralde, R.C. 1995. Fertilizer N, crop residue, and tillage alter soil $\mathrm{C}$ and $\mathrm{N}$ content in a decade. In: Soil Management and Greenhouse Effect. Advances in Soil Science, R. Lal et al. (eds.), pp. 93-99, CRC Lewis Publishers, Boca Raton, FL.

Ortega, R.A., Peterson, G.A.,Westfall, D.G. 2002. Residue accumulation and changes in soil organic matter as affected by cropping system intensity in no-till dry land agro ecosystems. Agronomy Journal, 94: 944-954.

Partey, S.T., Preziosi, R.F., Robson, G.D. 2014. Improving maize residue use in soil fertility restoration by mixing with residues of low $\mathrm{C}: \mathrm{N}$ ratio: Effects on $\mathrm{C}$ and $\mathrm{N}$ mineralization and soil microbial biomass. Journal of Soil Science and Plant Nutrition, 14: 518-531.

Poirier, V., Angers,D.A., Rochette, P., Whalen, J.K. 2013. Initial soil organic carbon concentration influences the short-term retention of crop-residue carbon in the fine fraction of a heavy clay soil. Biology and Fertility of Soils, 49: 527-535.

Potthoff, M., Dyckmans, J., Flessa, H., Muhs, A. 2005. Dynamics of maize leaf straw mineralization as affected by the presence of soil and availability of nitrogen. Soil Biology and Biochemistry, 37: 12591266.

Qian, P.,Schoenau, J. 2002. Availability of nitrogen in solid manure amendments with different $\mathrm{C} / \mathrm{N}$ ratios. Canadian Journal of Soil Science, 82: 219-225.

Rasmussen, P.E., Parton, W.J. 1994. Long-term effects of residue management in wheat-fallow. 1. Inputs, yield, and soil organic matter. Soil Science Society of America Journal, 58: 523-530.

Recous, S., Robin, D., Darwis, D., Mary, B. 1995. Soil inorganic $\mathrm{N}$ availability: effect on maize residue decomposition. Soil Biology and Biochemistry, 27: 1529-1538.

Rezig, F.A.M., Mubarak, A.R., Ehadi, E.A. 2013. Impact of organic residues and mineral fertilizer application on soil-crop system: II soil attributes. Archives of Agronomy and Soil Science, 59: 1245-1261.

Samra, J.S., Singh, B., Kumar, K. 2003. Managing crop residues in the ricewheat system of the IndoGangetic plain. In: Improving the Productivity and Sustainability of Rice-wheat Systems: Issues and Impact. ASA, Spec. Pub. 65, J. K. Ladha et al. (eds.), pp. 173-195. Madison, WI, ASA.

Sarkar, S., Rathore, T.R. 1992. Soil properties changes associated with wheat straw management. Indian Agriculturist, 43: 177-183.

Schjønning, P., Thomsen, I.K.,Moldrup, P., Christensen, B.T. 2003. Linking soil microbial activity to waterand air-phase contents and diffusivities. Soil Science Society of America Journal, 67: 156-165.

Singh, B.,Rengel, Z. 2007. The role of crop residues in improving soil fertility. In: Nutrient Cycling in teSRRestrial Ecosystems, Soil Biology, Marschner, P. and Z. Rengel (eds.) Springer.

Stark, J.M., Firestone, M.K. 1995. Mechanisms for soil moisture effects on activity of nitrifying bacteria. Applied and Environmental Microbiology, 61: 218221.

Stengel, P., Douglas, J.T., Guérif, J., Goss, M. J., Monnier, G., Cannell, R.Q. 1984. Factors influencing the variation of some properties of soils in relation to their suitability for direct drilling. Soil and Tillage Research, 4: 35-53.

Stevenson, F.J. 1986. The carbon cycle. In: Cycles of Soil, Carbon, Nitrogen, Phosphorus, Sulfur, Macronutrients. pp. 5-7. John Wiley, New York, USA.

Tisdall, J.M., Oades, J.M. 1982. Organic matter and water stable aggregation in soils. Journal of Soil 
Science, 33: 141-163.

Trinsoutrot, I., Recous, S., Bentz, B., Lineres, M., Cheneby, D., Nicolardot, B. 2000. Biochemical quality of crop residues and carbon and nitrogen mineralization kinetics under nonlimiting nitrogen conditions. Soil Science Society of America Journal, 64: 918-926.

Tulina, A.S., Semenov, V.M., Rozanova, L.N., Kuznetsova, T.V., Semenova, N.A. 2009. Influence of moisture on the stability of soil organic matter and plant residues. Eurasian Soil Science, 42: 12411248.

Van Kessel, J.S., Reeves, J.B.,Meisinger, J.J. 2000. Nitrogen and carbon mineralization of potential manure components. Journal of Environmental Quality, 29: 1669-1677.

Zhang, D., Hui, D., Luo, Y. 2008. Rates of litter decomposition in te SR Restrial ecosystems: global patterns and controlling factors. Journal of Plant Ecology, 2: 85-93. 